\title{
Causal Relationship between Public Investment and Economic Growth: Evidence from Bangladesh
}

\author{
Md. Sayeem - Bin - Hafiz ${ }^{1}$, Md. Tanvir Hasan ${ }^{2}$ \\ I (Lecturer, Department of Finance, Bangladesh University of Business and Technology (BUBT). \\ ${ }^{2}$ (Lecturer, Department of Finance, Bangladesh University of Business and Technology (BUBT).
}

\begin{abstract}
The paper explores the causal relationship between public investments and economic growth in the case of Bangladesh in the period 1976 - 2014, using a Vector Autoregression Model (VAR). Based on literature review, the model also includes private investment, inflation, real interest rate, money supply, and foreign direct investment besides public investment. The GDP growth rate is used as a measure of economic growth, but public investment along with private investment, money supply, and foreign direct investment is expressed as ratios of GDP. Our ECM model estimates indicate the existence of a long-run relationship between public investment and economic growth. According to the grander causality test this study shows that there exists no short run causal relationship between public investment and economic growth.
\end{abstract}

Keywords: Public Investment, Economic Growth, Cointegration Test, Private Investments, Gross Domestic Product (GDP), FDI

\section{Introduction}

Investment in any form plays a pivotal role to stimulate economic growth of any country hence results in productive outcomes (either at individual level or at national level). Investment provides the platform for capital formation which is thus channeled into production of goods and services, and by extension, economic growth. Investment in an economy broadly can be classified into domestic investment and foreign investment. (Abubakar \& Bala, 2016)[1]. Fatima (2012)[2] refers that at domestic level there are two kinds of investments, which are useful for the economic efficiency of a country. These include public investment and private investment. Economic theory suggests that public investment facilitates and stimulates private investment and FDI through the provision of social and economic infrastructural support. This increases overall productivity of capital, reduces production costs, gives rise to profit and sales expectations which in turn induce private investments. In addition, the growth impact of increased public investment depends on how it is financed. If it is financed through higher public debt, which implies higher future taxation levels, private investments may get crowded out.

As public investment is fully organized by government, so it is always on the favor of mass population. To solve the problems of basic human needs of a country, public investment can play a long term vital role. According to a study of UNCTAD (2009)[3], much public investment takes the form of infrastructural outlays for road and rail networks, ports, bridges, energy generating plants, water and sanitation networks, telecommunications structures, government buildings - which can have a productive life of several decades. Such outlays range from small, one-off, limited infrastructural projects that can be implemented within a year to more complex projects that take place over decades - so-called "mega projects". But other types of outlays, some of a more current form, can also contribute to capital formation.

Lloyd (1999)[4] defined public investment, as a result of the government policies; hence representing priorities of the political party in power. In general there are four different kinds of the public investment, such as investment on human capital (in the form of provision of education, and other basic needs); infrastructure (e.g. buildings, roads and other means of communications); research and development (e.g. in the form of technology adoption, investment in provision of technological equipments etc.) and general investment on the industries.Public investment is measured as general government gross fixed capital formation (GFCF) and comprises of total net value of general government acquisitions of fixed assets during the accounting period, plus variations in the valuation of non-produced assets. (IMF Staff Report, June 11, 2015)[5]. The role of public investment on economic growth can be figured as follows:

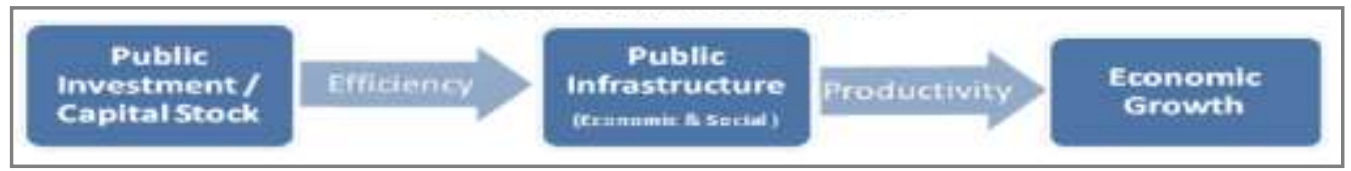

Figure 1: Role of Public Investment on Economic Growth

Source: IMF Staff Report, 2015 


\section{Public Investment Scenario In Bangladesh}

Public investment can play a vital role to improve the economic situation and level of economic development of Bangladesh like other countries where fiscal deficits are usual. Expenditure of government includes both the purchase of final goods and services, and transfer payments. Expenditures help government to undertake key functions, such as national defense and education subsidies, interest payment, social security and welfare, health, agriculture, public administration, local government and rural development, transportation and communication, industrial, energy and power, culture and religious affairs, and pension. The implementation of ADP is also important for increasing the productive capacity of the country. (Unnayan Onneshan, Aug, 2015)[6] The economy needs public investments in physical and social infrastructure to make up for shortfall of private investments to achieve the target GDP growth. The Government is aware that even with a strong public resource mobilization effort, total resources available will be limited in relationship to demand. The Government also recognizes that ensuring proper use of these scarce resources is very important. So, priorities are identified on the basis of realization of the key plan targets in relation to growth, poverty reduction, human development, equity and sustained development.

The Planning Commission (PC) is the supreme policy institution that oversees public investment management in Bangladesh. The PC advises the National Economic Council (NEC) chaired by the Prime Minister, and assumes broad and critical functions that extend from the formulation of development plans such as the Perspective Plan, Five-Year Plan, and Annual Development Program (ADP), to the selection, monitoring and evaluation of public investment projects under the ADP. Any capital outlay of a government would be defined as "public investment" in normal budgetary classification terms. In Bangladesh public investment has traditionally consisted of two components: ADP and non-ADP. In recent years, another component in the form of public-private partnership (PPP) has been added to public investment. The trends of public investment in line with private investment, and foreign direct investment (FDI) are illustrated in Fig. 2. The data are presented as percentage of GDP.The figure reveals that economic growth in Bangladesh appears to coincide with the growth of infrastructure capital in the hard infrastructure sectors; particularly energy, transport and communication. From FY 1994-95 the private investment starts to increase at sharp rate.

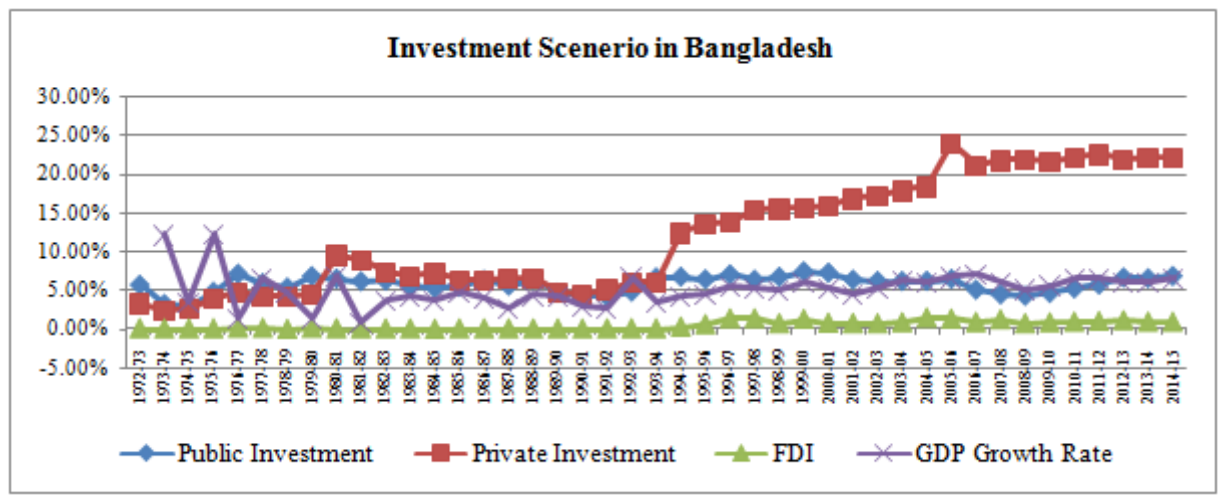

Figure 2: Investment Scenario in Bangladesh

Source: Different Issues of Bangladesh Bank (BB), Ministry of Finance (MoF), Bangladesh Bureau of Statistics (BBS) and United Nations Conference on Trade and Development (UNCTAD) and own calculations.

After suffering major setbacks in levels during the Liberation War and a slowdown in growth in its aftermath, Bangladesh's economy has accelerated since the end of the 1980s. The economy of Bangladesh has experienced an average of $4 \%$ plus growth per annum throughout the 1990s. Bangladesh experienced solid average annual growth of 6.3 percent between 2004 and 2008. In fiscal 2009, despite the global financial crisis, Bangladesh recorded 5.9 percent real GDP growth, only a 0.3 percentage point decline from 6.2 percent growth in fiscal 2008. According to the revised estimates, GDP growth rate in FY2011 was 5.16\%. This was due in large part to the generally sound macroeconomic policies implemented by the government over the period. Another significant characteristic is the reduced fluctuation in the country's annual economic growth. In the past, large variation in the growth rate, among others, was a significant factor that inhibited greater investment flow and reduced its productivity in Bangladesh. In short, the economy has now become more resilient having diversified sources of growth along with greater capacity to deal with short-term fluctuations. Trends in investment in Bangladesh show a decline in public sector participation, compared to the private sector in the country's economic activities. Relaxing of several restrictions on private investment in the industrial Policies of 1991 and 1992 including licensing requirements for private investment and opening up of telecommunications, power generations and domestic air transport to the private sector, has increased the private investment to GDP ratio over the year. This is a clear reflection of government policy to gradually withdraw government 
intervention and encourage the private sector in all spheres of economic activity. The success of the government in this area is reflected in the share of private sector investment in GDP, which increased to 19.5 percent in 2010-11 from 11.8 percent in 1993-94. On the other hand, public investment decreased from 6.6 percent in 1993-94 to 5.3 percent in 2010-11. (Haque, 2013) [7] The idea is that public investment might have a positive effect on economic growth. So, the objective of the study is to determine the causal relationship between public investment and economic growth in the context of Bangladesh.

\section{Literature Review}

There have been a number of studies done on countries with varying structures to examine whether public investment makes a distinct contribution to economic growth. MacMillan and Smyth (1994) [8] estimated the VAR models using both levels and first differences of the variables and concluded that public capital has negligible impacts on output.

A study of Khan (1996) [9] on a group of developing countries explores that private investment have a much larger impact on economic growth than public investment. Also, significant regional variations are found in terms of the effects of public and private investment.

Mittnik and Neumann (2001) [10] estimate a VAR with GDP, private investment, public investment and public consumption for six industrialized economies. Their results indicate that public investment tends to exert positive effects on GDP, and that there is no evidence of dominant crowding-out effects.

A study on the Southern African Customs Union (SACU) region by Ashipala and Haimbodi (2003) [11] looked at the relationship between public investment and economic growth in South Africa, Botswana, and Namibia using the VECM methodology. It was found that in all three cases the effect of public investment on growth was not statistically significant however; it did have the correct sign.

karim et. al (2005) [12] found that private and public investments do appear to have different effect on the long-economic growth of Bangladesh. In other words, the marginal productivity of private and public investment is differing in Bangladesh. Further private investment plays a much larger and thus more important role in the growth process of Bangladesh.

Ghani and Din (2006) [13] explored the relationship between public investment and economic growth for Pakistan economy. The study concluded that public investment had a negative, though insignificant impact on output. In contrast, there was a positive relationship between private investment and economic growth.

The study of Swaby (2007) [14] seeks to uncover the relationship between public investment and growth in Jamaica. It was found that although public investment had a positive impact on GDP, it was not significant. Public investment also crowed-out net private investment as it resulted in higher domestic private investment but lower foreign domestic investment, with the latter effect being much more substantial.

Study of Blin and Ouattara (2009) [15] indicates that foreign direct investment exerts a highly significant positive impact on economic growth in Mauritius. As for domestic investments, private investment shows positive and highly significant impact, whilst the effect of public investment is positive but only significant at 10 percent level.

Ellahi and Kiani (2011) [16] analyze the relationship between public investment and economic growth for Pakistan over the period 1975 to 2009. A disaggregated analysis showed that, there is a positive impact of public sector spending on economic growth of Pakistan in short run as well as long run.

Lean and Bee (2011) [17] investigated the relationship among growth, FDI and gross fixed capital formation as domestic investment for Malaysian economy for the period of 1970 to 2009. The results show that FDI has positive effect on growth while domestic investment has negative effect on growth while the major finding is that FDI crowd in domestic investment.

Study of Uddin and Aziz (2014)[18] explores the role of public investment in the process of economic growth of Bangladesh for the period 1973-2011 and found that public investment has positive effects on GDP.

\subsection{Data Source and Data Description}

\section{Research Methodology}

All pertinent data have been obtained from the International Statistic data bases (Bangladesh Bank, BBS, MOF, World Bank, and UNCTAD). The researcher chose the period 1976-2014 for the analysis in this paper; this allows considering the association between public investment and economic growth of the country. The primary variable of interest is the economic growth; the GDP growth rate has been taken as a measure of economic growth. Other variables including public investment, private investment, and money supply are scaled to GDP. This choice of variables allows focusing on the effects of public spending on economic growth.

\subsection{Operational Definitions of the Variables}

Economic Growth: An economy's growth is measured by the change in the volume of its output or in the real incomes of its residents. The volume of GDP is the sum of value added, measured at constant prices, by 
households, government, and industries operating in the economy. GDP accounts for all domestic production, regardless of whether the income accrues to domestic or foreign institutions. (World Bank)

Public Investment: Public investment can play a vital role to improve the economic situation and level of economic development of a country. Public investment is a result of the government policies; which consists of investment in human capital, infrastructure, R\&D and general investment on the industries. In Bangladesh public investment has traditionally consisted of two components: ADP and non-ADP. In recent years, another component in the form of public-private partnership (PPP) has been added to public investment.

Private Investment: Private investment covers gross outlays by the private sector on additions to its fixed domestic assets. Private investment refers to investment by private business for the purpose of profit generation (Kumo, 2006) [19].

Foreign Direct Investment: FDI means investment of foreign capital by a person who is not a citizen of Bangladesh or by a company incorporated outside Bangladesh, in the form of foreign exchange, imported machinery and equipment, or in such other form as the Government may approve for the purpose of such investment. Direct investment is a category of cross-border investment associated with a resident in one economy having control or a significant degree of influence on the management of an enterprise that is resident in another economy.

Interest Rate: Interest rate has an important role in economic growth. Higher interest rates reduce the growth of consumer spending and economic growth. This is because high interest rate creates more incentive to save rather than spend, makes borrowing more expensive, therefore less spending on credit and less investment. Consequently, an inverse relationship is expected between interest rate and economic growth. (World Bank)

Inflation: Inflation is another significant variable influencing output growth rate. In general, very high levels of inflation may undermine economic growth. However if the inflation rate is low, stable and sustainable, it may be interpreted as an indicator of macroeconomic stability that would enhance growth. Hence, we expect to get inverse relationship with output growth. (Duokit and Ekong, 2016)[20].

Financial Deepening: Financial deepening is measured by the ratio of M2 to GDP essentially seek to capture the role of the financial sector development in economic growth. In modern economic theory the role of the financial sector is seen to be catalytic to the growth of the economy. (Duokit and Ekong, 2016)[20]

The list of variables, definitions and notation is summarized in Table $\mathbf{1}$ below:

Table 1: Measurement and Notation of the Variables

\begin{tabular}{|l|l|l|}
\hline Variable Name & Measurement & Notation \\
\hline Economic Growth & Annual Growth Rate of GDP & GDPGR \\
\hline Public Investment & Public Investment / GDP & PIV \\
\hline Private Investment & Private Investment / GDP & PRI \\
\hline Foreign Direct Investment & Foreign Direct Investment / GDP & FDI \\
\hline Financial Deepening & Money Supply (M2) / GDP & M2 \\
\hline Inflation & Consumer Price Index & INF \\
\hline Interest Rate & Real Interest Rates as measured by the GDP deflator & RIR \\
\hline
\end{tabular}

\subsection{Research Design}

To conduct the study both descriptive and econometric analyses have been implemented. For the purpose of descriptive statistics mean and standard deviations have been calculated of the countries concerned to pinpoint the central distribution and graphical analysis have been used to figure out the trend of the selected variables during the study period (1976-2014). Therefore, first part of this study describes the following analysis to identify the relationship and trend of the variables used in the study:

$>$ Descriptive Statistics $^{1}$

$>$ Graphical Analysis

$>$ Stationarity Test (Unit Root Test)

$>$ Cointegration Test

The study deals with some important macroeconomic variables. For that purpose Stationarity test, Cointegration test along with Granger Causality test of the variables have been executed using STATA v. 9.0 and Microsoft EXCEL.

\footnotetext{
${ }^{1}$ Mean and standard deviation of Money Supply, Inflation, and Deficit of the selected countries

DOI: 10.9790/5933-0704043140 $\quad$ www.iosrjournals.org $34 \mid$ Page
}




\subsection{Model Specification}

\subsubsection{Unit Root Test}

For the purpose of the study macroeconomic variables have been chosen. Macroeconomic variables are supposed to be non-stationary (Nelson and Plosser, 1982)[21] and unless they are cointegrated are conducive to spurious regression. So, stationarity of the series has to be examined. For this reason, an Augmented DickeyFuller $(\mathrm{ADF})$ test has been conducted by carrying out a unit root test based on the subsequent formation:

$$
\Delta M_{t}=u+\emptyset t+\partial M_{t-1}+\sum_{i=1}^{k} \infty_{i} \Delta M_{t-i}+\varepsilon_{t}
$$

Where $M$ is the variable under consideration (public investment, economic growth in terms of GDP growth rate along with foreign direct investment, private investment, real interest rate, inflation, money supply (M2) as supporting variables), $\Delta$ is the first difference, $t$ designates time trend, $\varepsilon t$ is a random error, and $k$ is the maximum lag length. $\emptyset, \partial, u$, and $\infty$ are the anticipated parameters. For that analysis the null hypothesis is that the series have unit root and therefore is non stationary and the alternative hypothesis is that there exists stationarity among the series considered. If the null hypothesis cannot be rejected, then it can be concluded that the series under consideration has a unit root and is therefore non-stationary.

\subsubsection{Cointegration Test}

With a view to conducting this study Johansen and Juselius (1998)[22] maximum likelihood cointegration technique is used, which tests both the existence and the number of cointegrating vectors. When non stationary time series become stationary after differencing then we can say the series is cointegrated. This cointegration test can be stated as

$$
X_{t}=K_{1} X_{t-1}+K_{2} X_{t-2}+\cdots+K_{k-1} X_{t-k}+\mu+\varepsilon_{t}
$$

Where, $X_{t}$ is the variable under consideration (public investment, private investment, foreign direct investment, GDP growth rate, inflation, real interest rate, and money supply). $K_{i}$ are $3 \times 3$ matrices of factors, $\mu$ is a vector of constant and $\varepsilon_{t}$ is random error term. Two likelihood ratio tests developed by Johansen: trace test $\left(\tau_{\text {trace }}\right)$ and maximum eigenvalue test $\left(\tau_{\max }\right)$ are used to find out the number of cointegrating vectors. It is prudent to rely on the evidence based on the $\left(\tau_{\max }\right)$ test if there exists any deviation of outcomes between these two tests, because according to Dutta and Ahmed (1997)[23] and Odhiambo (2005)[24] it is more consistent in small samples.

\subsubsection{Model on Granger Causality}

To examine the causal relationship among the variables of interest a trivarate Granger Causality Model is utilized. The apposite design of the model depends on the status of the unit roots of the variables of interest and on the existence of co-integration between the variables. If variables are cointegrated, then there exists causal relationship between variables (either unidirectional or bidirectional). Theoretically, if the current or lagged terms of a variable, for example $X_{t}$ determine another variable, for example $Y_{t}$, then there exists a causal link between $X_{t}$ and $Y_{t}$ in which $Y_{t}$ is Granger-caused by $X_{t}$. Thus, the model is specified as follows

$\Delta Y_{t}=\varphi_{11} \Delta Y_{t-1}+\cdots+\varphi_{1 n} \Delta Y_{t-n}+\varphi_{21} X_{t-1}+\cdots+\varphi_{2 n} X_{t-n}-\gamma_{1}\left(Y_{t-1}-a X_{t-1}-b\right)+\varepsilon_{1 t}$ $\Delta X_{t}=\varphi_{31} \Delta X_{t-1}+\cdots+\varphi_{3 n} \Delta X_{t-n}+\varphi_{41} \Delta Y_{t-1}+\cdots+\varphi_{4 n} \Delta Y_{t-n}-\gamma_{2}\left(Y_{t-1}-a X_{t-1}-b\right)+\varepsilon_{2 t}$

The following hypotheses are justified using the above two models to evaluate the causal relationship between the variables:

If $\varphi_{21}=\cdots=\varphi_{2 n}=\gamma_{1}=0$, then $X_{t}$ does not granger cause $Y_{t}$ If $\varphi_{41}=\cdots=\varphi_{4 n}=\gamma_{2}=0$, then $Y_{t}$ does not granger cause $X_{t}$

\subsection{Descriptive Statistics}

\section{Results And Discussion}

Data analyzed to this study have been collected covering the period of 1976-2014. Table 2 demonstrates the summary statistics of the study. Data are collected from central bank of Bangladesh.

Table 2: Descriptive Statistics

\begin{tabular}{|l|l|l|l|l|l|l|l|}
\hline & PRI & PVI & FDI & M2 & GDPGR (\%) & INF (\%) & RIR (\%) \\
\hline Mean & $625,758.4$ & 191,030 & $27,320.74$ & $1,378,437$ & 0.0498 & 0.07391 & 0.07045 \\
\hline Standard Error & $144,003.4$ & $39,288.4$ & $6,138.659$ & $323,300.2$ & 0.0031 & 0.00638 & 0.01142 \\
\hline Median & $207,315.5$ & 104,758 & $6,501.361$ & 439,514 & 0.0514 & 0.07255 & 0.07616 \\
\hline Mode & N/A & N/A & N/A & N/A & 0.0420 & 0.0279 & N/A \\
\hline St. Dev. & $910,757.5$ & 248482 & 38824.29 & $2,044,730$ & 0.0197 & 0.0404 & 0.07224 \\
\hline Variance & 0.00000 & 0.00000 & 0.00000 & 0.00000 & 0.0003 & 0.0016 & 0.00521 \\
\hline
\end{tabular}


Causal Relationship between Public Investment and Economic Growth: Evidence from Bangladesh

\begin{tabular}{|l|l|l|l|l|l|l|l|}
\hline Kurtosis & 1.88516 & 3.9511 & 1.365776 & 2.968291 & 3.7080 & 2.1057 & 5.46890 \\
\hline Skewness & 1.68334 & 2.05553 & 1.518735 & 1.931391 & 0.6880 & -0.2206 & 0.72664 \\
\hline Range & $3,340,488$ & $1,028,798$ & $132,222.1$ & $7,862,169$ & 0.1140 & 0.2322 & 0.46395 \\
\hline Minimum & 4,212 & 5,202 & -166.1 & 13,968 & 0.0080 & -0.0529 & -0.11637 \\
\hline Maximum & $3,344,700$ & 1034000 & 132056 & $7,876,137$ & 0.1220 & 0.1793 & 0.34758 \\
\hline Sum & $2,5030,335$ & $7,641,198$ & $1,092,830$ & $55,137,479$ & 1.9939 & 2.9564 & 2.81831 \\
\hline Count & 40 & 40 & 40 & 40 & 40 & 40 \\
\hline Note: All the variables are expressed in million BDT except GDPGR, INF and RIR. \\
\hline
\end{tabular}

Source: Author's estimation

The summary statistics disclose that all the series exhibit a high level of reliability as their mean and median are within the maximum and minimum values of the series. Also, the standard deviations showing the deviations of the actual data from their mean values are relatively low.

\subsection{Stationarity Test}

For the stationarity test of the variables Augmented Dickey Fuller (ADF) Unit Root Tests has been conducted. The null hypothesis is that the variable is non stationary and the alternative hypothesis is that there exists stationarity. A stationary time series data is one whose statistical properties such as mean, variance, autocorrelation, etc. are all constant over time. Most statistical analysis is based on the assumption that the time series can be rendered approximately stationary.

Table 3: Augmented Dickey Fuller (ADF) Unit Root Tests

\begin{tabular}{|l|l|}
\hline Variables & Stationarity Status ( at 5\% level of significance) \\
\hline PRI & Non stationary. But stationary after taking $1^{\text {st }}$ difference. \\
\hline PIV & Stationary \\
\hline FDI & Stationary \\
\hline M2 & Non stationary. But stationary after taking $1^{\text {st }}$ difference. \\
\hline GDPGR & Stationary \\
\hline INF & Stationary \\
\hline RIR & Stationary \\
\hline
\end{tabular}

From the Table 3 it is evident that all the variables are stationary at level as their test statistics are higher than the critical values except for private investment and M2. Hence the null hypothesis of non stationarity is not rejected in that case. It is also apparent that the variables that are non stationary at level are stationary after taking the $1^{\text {st }}$ difference.

\subsection{Cointegration Test}

The presence and the number of co-integrating relationships among the underlying variables are tested through a vector error correction model applying the Johansen procedure. To test for cointegration it should be specified how many lags to be included. If there exists a stationary linear combination of nonstationary random variables, the variables combined are said to be cointegrated. Since it is unknown that the appropriate lag structure to be used therefore, lag length selection test ${ }^{2}$ have been carried out.

Table 4: Cointegration Test

\begin{tabular}{|l|l|l|l|l|l|l|l|}
\hline Lag & LL & LR & Df & P & AIC & HQIC & SBIC \\
\hline 0 & 46.9291 & & & & -2.10153 & -1.9942 & -1.79987 \\
\hline 1 & 202.448 & 311.04 & 49 & 0.000 & -7.70777 & -6.84915 & -5.29449 \\
\hline 2 & 308.372 & $211.85^{*}$ & 49 & 0.000 & $-10.7038^{*}$ & $-9.09388^{*}$ & $-6.1789^{*}$ \\
\hline
\end{tabular}

Source: Author's estimation

From Table 4 it is perceived that Hannan-Quinn information criterion (HQIC) method selects two lags, Schwarz Bayesian information criterion (SBIC) method selects two lags, sequential likelihood-ratio (LR) selects two lags as indicated by the "*" in the output. Since the variables are stationary at $1^{\text {st }}$ difference Johansen tests of cointegration has been applied as shown in Table 5.

Table 5: Johansen Tests for Cointegration

\begin{tabular}{|l|l|l|l|l|}
\hline Maximum Rank & LL & Eigen value & Trace Statistics & 5\% critical value \\
\hline 0 & 192.59346 & & 231.5577 & 124.24 \\
\hline 1 & 242.22872 & 0.92664 & 132.2872 & 94.15 \\
\hline 2 & 273.80574 & 0.81023 & 69.1331 & 68.52 \\
\hline 3 & 292.48731 & 0.62590 & $31.7700^{*}$ & 47.21 \\
\hline
\end{tabular}

\footnotetext{
${ }^{2}$ In the process of determining lag length fixed maximum lag length of two has been selected sample size is too small.

DOI: $10.9790 / 5933-0704043140 \quad$ www.iosrjournals.org $36 \mid$ Page
}




\begin{tabular}{|l|l|l|l|l|}
\hline 4 & 299.22484 & 0.29855 & 18.2949 & 29.68 \\
\hline 5 & 303.94486 & 0.21997 & 8.8549 & 15.41 \\
\hline 6 & 307.49127 & 0.17027 & 1.7621 & 3.76 \\
\hline 7 & 308.37230 & 0.0453 & & \\
\hline
\end{tabular}

Source: Author's estimation

To tests cointegration Johansen's method has been used. Test statistics are based on a model with two lags and a constant trend. Table 5 presents test statistics and their critical values of the null hypotheses of no cointegration and one or fewer cointegrating equations. The eigenvalue shown on the last line is used to compute the trace statistic in the line above it. Johansen's testing procedure starts with the test for zero cointegrating equations (a maximum rank of zero) and then accepts the first null hypothesis that is not rejected. Johansen's testing procedure starts with the test for zero cointegrating equations and then accepts the first null hypothesis that is accepted. In the output above, the null hypothesis of no cointegration has been rejected and the null hypothesis of at most three cointegrating equations is not rejected. Thus, the null hypothesis that there are maximum three cointegrating equations in the model is accepted. Hence the variables are conintegrated meaning that they have association in the long run.

\subsection{Error Correction}

Based on the stationary and cointegration estimates, the causal nexus between economic growth and public investment is examined by the Vector Error Correction (VEC) causality equation. The result of the VEC causality estimate is presented on Table $\mathbf{6}$ and from the table it is observed that for cointegrating equation with GDP growth rate as dependent variable was significant at five per cent, that there is long run causality running from economic growth in terms of GDP growth to private and public investment, foreign direct investment, money supply, inflation, and real interest rate.

Table 6: VECM Model

\begin{tabular}{|l|l|l|l|}
\hline Variables & GDPGR & Coefficients & $\mathbf{P}>|\mathbf{z}|$ \\
\hline Dependent variable & -1.072708 & 0.000 \\
\hline \multirow{4}{*}{ Independent variables } & PRI & -1.079407 & 0.004 \\
\cline { 2 - 4 } & PIV & .3974949 & 0.426 \\
\cline { 2 - 4 } & FDI & .1251255 & 0.001 \\
\cline { 2 - 4 } & M2 & 1.409636 & 0.125 \\
\cline { 2 - 4 } & INF & .2144055 & 0.095 \\
\cline { 2 - 4 } & RIR & -.0428362 & 0.740 \\
\hline Constant & -.0310857 & 0.174 \\
\hline
\end{tabular}

Source: Author's estimation

To test for serial correlation in the residuals Lagrange-multiplier test for residual autocorrelation has been conducted. From Table 7 it is apparent that there is no residual autocorrelations up to three lag lengths at $5 \%$ level of significance.

Table 7: Lagrange-Multiplier Test for Residual Autocorrelation

\begin{tabular}{|l|l|l|l|}
\hline Lag & chi2 & df & Prob > chi2 \\
\hline 1 & 76.2293 & 49 & 0.00764 \\
\hline 2 & 62.2785 & 49 & 0.09640 \\
\hline 3 & 48.8193 & 49 & 0.48040 \\
\hline
\end{tabular}

Source: Author's estimation

To check whether the residuals are normally distributed Jarque-Bera test has been conducted and here the null hypothesis is that the residuals or variances are normally distributed. It is apparent from Table 8 that for the first model of private investment the null hypothesis is not rejected at $5 \%$ level of significance. This is true for rest of the models of FDI, M2, real interest rate, inflation, and GDP growth.

Table 8: Jarque-Bera Test

\begin{tabular}{|l|l|l|l|}
\hline Equation & chi2 & df & Prob > chi2 \\
\hline Log PRI & 0.910 & 2 & 0.63439 \\
\hline Log FDI & 2.109 & 2 & 0.34830 \\
\hline Log M2 & 1.602 & 2 & 0.44895 \\
\hline Log GDPGR & 1.766 & 2 & 0.41357 \\
\hline Log INF & 1.549 & 2 & 0.46103 \\
\hline Log RIR & 3.146 & 2 & 0.20739 \\
\hline ALL & 11.768 & 14 & 0.62497 \\
\hline
\end{tabular}

Source: Author's estimation 


\subsection{Granger Causality Model}

After fitting the coinegration test, it should be verified whether one variable "Granger-causes" another (Granger 1969). Following table shows the variables under consideration along with their respective Prob>chi2.

Table 9: Granger Causality Wald Tests

\begin{tabular}{|c|c|c|c|c|}
\hline Equation & Excluded & chi2 & $\mathrm{df}$ & Prob>chi2 \\
\hline Log GDPGR & Log PRI & 5.823 & 2 & 0.054 \\
\hline Log GDPGR & Log PIV & 3.9899 & 2 & 0.136 \\
\hline Log GDPGR & Log FDI & .03959 & 2 & 0.980 \\
\hline Log GDPGR & Log M2 & 5.5218 & 2 & 0.063 \\
\hline Log GDPGR & Log INF & .2176 & 2 & 0.897 \\
\hline Log GDPGR & Log RIR & 10.992 & 2 & 0.004 \\
\hline Log GDPGR & ALL & 67.301 & 12 & 0.000 \\
\hline Log PRI & Log PIV & 6.5752 & 2 & 0.037 \\
\hline Log PRI & Log FDI & 1.9363 & 2 & 0.380 \\
\hline Log PRI & Log M2 & 52054 & 2 & 0.771 \\
\hline Log PRI & Log GDPGR & 3.7395 & 2 & 0.154 \\
\hline Log PRI & Log INF & 17.143 & 2 & 0.000 \\
\hline Log PRI & Log RIR & 7.6125 & 2 & 0.022 \\
\hline Log PRI & ALL & 43.17 & 12 & 0.000 \\
\hline Log PIV & Log PRI & .33585 & 2 & 0.845 \\
\hline Log PIV & Log FDI & 3.041 & 2 & 0.219 \\
\hline Log PIV & Log M2 & .24469 & 2 & 0.885 \\
\hline Log PIV & Log GDPGR & .16171 & 2 & 0.922 \\
\hline Log PIV & Log INF & 2.0306 & 2 & 0.362 \\
\hline Log PIV & Log RIR & .14895 & 2 & 0.928 \\
\hline Log PIV & ALL & 7.8254 & 12 & 0.799 \\
\hline Log FDI & Log PRI & 30.968 & 2 & 0.000 \\
\hline Log FDI & Log PIV & 4.3756 & 2 & 0.112 \\
\hline Log FDI & Log M2 & 7.179 & 2 & 0.028 \\
\hline Log FDI & Log GDPGR & 28.035 & 2 & 0.000 \\
\hline Log FDI & Log INF & 4.6587 & 2 & 0.097 \\
\hline Log FDI & Log RIR & 3.9412 & 2 & 0.139 \\
\hline Log FDI & ALL & 75.298 & 12 & 0.000 \\
\hline Log M2 & Log PRI & 8.5014 & 2 & 0.014 \\
\hline Log M2 & Log PIV & 9.521 & 2 & 0.009 \\
\hline $\log M 2$ & Log FDI & 5.3239 & 2 & 0.070 \\
\hline $\log M 2$ & Log GDPGR & 1.2912 & 2 & 0.524 \\
\hline Log M2 & Log INF & 11.117 & 2 & 0.004 \\
\hline $\log M 2$ & Log RIR & 4.2252 & 2 & 0.121 \\
\hline $\log$ M2 & ALL & 45.782 & 12 & 0.000 \\
\hline Log INF & Log PRI & 2.8849 & 2 & 0.236 \\
\hline Log INF & Log PIV & .07256 & 2 & 0.964 \\
\hline Log INF & Log FDI & 6.958 & 2 & 0.031 \\
\hline Log INF & $\log M 2$ & .80173 & 2 & 0.670 \\
\hline Log INF & Log GDPGR & .18535 & 2 & 0.911 \\
\hline Log INF & Log RIR & 12.1 & 2 & 0.002 \\
\hline Log INF & ALL & 22.314 & 12 & .034 \\
\hline Log RIR & Log PRI & .99467 & 2 & 0.608 \\
\hline Log RIR & Log PIV & 3.7889 & 2 & 0.150 \\
\hline Log RIR & Log FDI & 12.829 & 2 & 0.002 \\
\hline Log RIR & $\log M 2$ & 3.8757 & 2 & 0.144 \\
\hline Log RIR & Log GDPGR & 4.5847 & 2 & 0.101 \\
\hline Log RIR & Log INF & .94616 & 2 & 0.623 \\
\hline Log RIR & ALL & 59.487 & 12 & 0.000 \\
\hline
\end{tabular}

Source: Author's estimation

Consider the results of the three tests for the first equation. Last test is with respect to the null hypothesis of all variables. In that case the null hypothesis is rejected. For that test the null hypothesis is that variables of interest like private investment, public investment, FDI, M2, interest rate, and inflation do not separately or jointly granger cause ( as Prob>chi2>.05) economic growth. In that case the null hypothesis is rejected for all of the variables except for real interest rate that means only real interest rate granger cause economic growth. However all of the variables jointly cause economic growth. Similarly the second equation of private investment it is apparent that only inflation granger cause private investment. Like the first equation of GDP all of the variables jointly granger cause private investment. In case of public investment equation none of the variables either jointly of separately granger cause public investment. In case of FDI only private investment and economic growth granger cause FDI. However all of the variables granger cause FDI. The 
money supply equation shows the causal relationship between money supply and public investment as well as inflation and money supply. All of the variables jointly granger cause M2 though. The same conclusion can be made in case of the equation of inflation and real interest rate. In case of the equation of inflation and real interest rate all of the variables of concern jointly granger cause both inflation and real interest rate. But there exists a causal relationship between inflation and real interest rate and between FDI and inflation. The same causal relationship exists between FDI and real interest rate.

\section{Conclusion}

The paper used a VECM to assess the impact of public investment on economic growth of Bangladesh using data from fiscal year 1976 to 2014 . The Granger causality result suggests that public investment does not cause economic growth in short run. Nonetheless, it was found that there exists a stable long-run relationship between the variables used in the model as the cointegration analysis indicated at least three cointegrating equation. The VECM showed that that there is long run causality running from economic growth in terms of economic growth to public investment. However, we also found that long run causality between economic growth and private investment, foreign direct investment, money supply, inflation, and real interest rate. Apparently, the result of the study shows that, in the case of Bangladesh, there are a lot of other factors that can stimulate economic growth, which have higher trend multiplier effects. It is virtually impossible for an economist to prove that one economic occurrence in the real world caused another. Thus, the results of this study cannot be considered to be conclusive. But we can suggest that the government should create more incentive for private domestic investment in the new high value-added sectors. What is more, to attract potential investors in high value-added activities the government should complement the existing policies with initiatives to simplify and speed the bureaucracy which remains cumbersome. Favorable local and international economic context, the relatively good infrastructures, the presence of private investors ready to invest, and the availability of cheap educated female labor force in the EPZ were sufficient to attract FDI and generate benefits for the economy. The guiding principle for public investment should be complimentary rather than compete with private investment. One of the limitations of the study is that it uses annual time series data, which may evade some important dynamic aspects. An analysis based on quarterly or monthly data should certainly be more enriching. Further studies can be carried out by taking a range of developing countries. Not only that, disaggregated public investment can be considered to highlight which elements of public investment have the greatest impact on growth, which have a positive impact on domestic private investment and FDI, and which elements crowd-out them.

\section{References}

[1]. Abubakar, A. B. and Bala, A. J. (2016), Nexus Between Domestic Investment, FDI and Economic Growth: Empirical Evidence from India, International Journal of Management, Accounting and Economics, 3(3), 174-184.

[2]. Fatima, G. (2012), Joint impact of investment (public and private) on the economic growth of Pakistan: (co-integration approach), International Journal of Humanities and Social Science, 2(15), 171-176.

[3]. UNCTAD (2009), Public investment: Vital for Growth and Renewal, but should it be Countercyclical Instrument?, The role of public investment in the social and economic development proceedings of the international conference in New York and Geneva: United Nations 2009.

[4]. Lloyd, P. (1999), The Regional Development Agencies and Social Inclusion: Widening the Agenda, Environment and Planning CGovernment and Policy, 17(6), 701-713.

[5]. IMF (2015), Making Public Investment More Efficient”. Washington, DC: IMF

[6]. Unnayan Onneshan (2015), Revenue Mobilization: Recent Trends, Bangladesh Economic Update, 6(7).

[7]. Haque, S. T. (2013), Effect of Public and Private Investment on Economic Growth in Bangladesh: An econometric Analysis, Research Study Series, No-FDRS 05/2013, 104-126.

[8]. Macmillan, W. and Smyth, D. (1994), A Multivariate Time Series Analysis of the United State Aggregated Production Function, Empirical Economics, 19, 659-673.

[9]. Khan, M. S. (1996), Government Investment and Economic Growth in the Developing World, The Pakistan Development Review, $35,419-439$.

[10]. Mittnik, S. and T. Neumann (2001). Dynamic effects of public investment: Vector autoregressive evidence from six industrialized countries. Empirical Economics 26(2), 429-444

[11]. Ashipala, J. and Haimbodi N. (2003), The Impact of Public Investment on Economic Growth in Namibia, Namibian Economic Policy Research Unit, Working Paper no 88.

[12]. Karim, N., Rahaman, M. M., and Ali, M. H. (2005), Private Investment and Economic Growth in Bangladesh: An Empirical Investigation, Pakistan Journal of Social Science, 3(1), 152-156.

[13]. Ghani, E. and Din, M. (2006), The Impact of Public Investment on Economic Growth in Pakistan, The Pakistan Development Review, 45(1), 87-98.

[14]. Swaby, R. (2007), Public Investment and Growth in Jamaica. Bank of Jamaica.

[15]. Blin, M. and Ouattara, B. (2008), Foreign direct investment and economic growth in Mauritius: Evidence from bounds test cointegration, Économie international, 117(1), 47-61.

[16]. Ellahi, N. \& Kiani, A. (2011), Investigating public investment-growth nexus for Pakistan, International Conference on E-business, Management and Economics, 25, 239-244.

[17]. Lean, H. H. and Tan, B. W. (2011), Linkages between foreign direct investment, domestic investment and economic growth in Malaysia. Journal of Economic Cooperation and Development, 32(4), 75-96. 
[18]. Uddin, M. and Aziz, S. (2014), Effect of Public Investment on Economic Growth in Bangladesh: An Econometric Analysis, Journal of Economics and Sustainable Development, 5(22), 37-50.

[19]. Kumo, W. L. (2006), Macroeconomic Uncertainty and Aggregate Private Investment in South Africa, South African Journal of Economics, 74(2), 190-204.

[20]. Duokit, E. O. and Ekong, C. N. (2016), Budget Deficit and Economic Growth in Sierra Leone: An Empirical Re- Examination", Journal of Business and Human Resource Management, 2(1).

[21]. Nelson, R. and Plosser, I. (1982), Trends and random walks in macroeconomic time series, Journal of Monetary Economics, 10, 139-162.

[22]. Johansen, S., and K. Juselius (1990), Maximum likelihood estimation and inference on cointegration with applications to the demand for money, Oxford Bulletin of Economics and Statistics, 52, 169-210.

[23]. Dutta and Ahmed (1997), "An Aggregate Import Demand Function for Bangladesh: A Cointegration Approach", Working Paper, No. 9703, Department of Economics and Business, Sydney: University of Sydney.

[24]. Odhiambo, Nicholas M., (2005), "Financial Liberalization and Financial Deepening: Evidence from Three Sub-Saharan African Countries", African Review of Money, Finance and Banking (Savings and Development Supplement), 19(1), 5-23. 